\title{
Social and Health Inequalities in Rich and Developed Countries: The Role of Sociology and Suggestion of Future Sociological Agendas
}

\author{
Jason Hung \\ y.hung@warwick.ac.uk
}

\begin{abstract}
In the early 1840s, Friedrich Engels and Rudolph Virchow argued that the "mode of social organization" was a lens through which the social patterning of disease could be understood (Scambler, 2012: 131). Virchow was reluctant to attribute disease to individual behaviour, and asserted that illness belonged to the discipline of social science (de Maio, 2010: 20). In the late 20th century Richard G. Wilkinson, a British social epidemiologist and a professor at University of Nottingham, echoed Engels and Virchow, postulating that Emile Durkheim, if he remained alive, would analyse suicide based on the modern burden in developed societies (Wilkinson, 1996: 15). The Marmot Review (2010: 16), a report initiated by Professor Michael Marmot of University College London proposing evidence-based and strategic solutions for health inequalities in England post-2010 states, "The serious health inequalities...cannot be attributed simply to genetic makeup, "bad", unhealthy behavior, or difficulties in access to health care... Social and economic differences in health status reflect...social and economic inequalities in society." Graham Scambler, after extensive investigations into health inequalities, derived the "greedy bastards hypothesis" (GBH). He believes social researchers should focus on studying a hardcore group of global capitalists, with wealth and authority, in order to develop a more nuanced understanding of the nature and extent of health inequalities (Gabe et al., 2013: 5) (Scambler, 2002). This essay will therefore assess socioeconomic impacts on health inequalities, while also incorporating psychosocial factors, as suggested by Scambler, in rich, developed countries. Furthermore, the roles of sociology and implied sociological agendas upon health inequalities will be discussed.
\end{abstract}

Key-words: Social and Health Inequalities, Sociological Agendas

Date of Publication: 30.06 .2018

DOI: 10.24297/jssr.v12i2.7479

ISSN: 2321-1091

Volume: 12 Issue: 2

Journal: Journal of Social Science Research

Publisher: CIRWORLD

Website: https://cirworld.com

This work is licensed under a Creative Commons Attribution 4.0 International License. 


\section{Class and Health Inequalities}

In the 1990s, Wilkinson, with regard to rich and developed countries, argued that nations with high rates of smoking are among the healthiest countries, including the Republic of Korea, Luxembourg and Belgium, despite cigarettes imposed potential risks for individuals' health (The Tobacco Atlas, 2015; Action on Smoking and Health, 1993). Rather than inferring that smoking is a habit with moderate level of harm, Wilkinson believes there should be further factors impacting the social gradients in health and illness (Wilkinson, 1996: 17). In response to Wilkinson, Ellen Annandale (2010) perceives gender, ethnic and spatial relations as contributing factors towards health inequalities. However, she asserts that none are as significant as class or socioeconomic classification (SEC) (Annendale, 2010). As early as 1976, the General Household Survey revealed the negative correlation between the rise of "long-lasting illness" and the fall of "socioeconomic status". In the survey, unskilled manual workers experienced a threefold volume of chronic illnesses in comparison with their professional counterparts (Townsend et al., 1988: 54). Despite the fact that The Black Report (1980) acknowledges that class might not be a direct attributor to health inequalities, it states that socioeconomic factors derived from class foster these inequalities. In the report, middle-class children are highlighted as a privileged group who can study in better-equipped schools, and consequently enjoy more prosperous careers after graduation. With higher salaries, they are able to access to better health care services (Townsend et al., 1988: 113).

\section{Income and Health Inequalities}

With respect to the findings of the Health and Lifestyle Survey, Mildred Blaxter (1990) asserts that, "these analyses support the conclusion that the apparently strong association of social class and health is primarily an association of income and health" (Blaxter, 1990: 72). With regard to the GBH, as proposed by Scambler, the maldistribution of wealth and income is deemed to have a pivotal influence on health inequalities (Scambler, 2002: 5). He further argues that income is the leading socioeconomic factor for health inequalities in the material approach, the second approach to interpreting health inequalities in accordance with his philosophy (Scambler, 2015). This approach relies less on individual behavior and instead shifts focus to socio-individual dynamics. While income level was initially seen as a contributing factor to health inequalities, Wilkinson reasserts his reluctance to draw an equivalent line between the two. He cites the impotence of the rise in living standards in Britain to explain its widening health inequalities over the last 50 years (Wilkinson, 1996: 3). Collin McCord and Harold P. Freeman correspondingly present another study in the United States in the late $20^{\text {th }}$ century, where black people in Harlem, across most age categories, suffered from higher mortality rates than corresponding individuals in rural Bangladesh (McCord and Freeman, 1990: 173-7). However, the Multiple Risk Factor Intervention Trial contained data which seemed to indicate that there is an insignificant relationship between ascending income level and descending death rate among the 300,000 tested men (Smith et al., 1992: 265-70). Applying a similar approach on an international scale, despite the progressive rise in Gross National Product per head among rich and developed countries, Gerry Rodgers has found an embarrassing and almost non-existent improvement in the life expectancy level in 23 countries in the Organization for Economic Cooperation and Development (OECD, 1991) from the 1970s to 1980s (Rodgers, 1979: 343-51).

Nevertheless, in another cross-sectional study, Wilkinson found statistical evidence of a correlation coefficient above 0.8 , between lower mortality rates and a more egalitarian distribution of income (Wilkinson, 1986: 88114). Michael Marmot and Davey Smith, in response, found Japan, as the nation with the most egalitarian income distribution on record, enjoys the privilege of the highest life expectancy worldwide (Marmot et al., 1989: 1547-51). In contrast, the widening income distribution in Britain has been in parallel with increasing mortality among men and women aged 15-44 since the mid-1980s (Department of Health, 1990). Wilkinson concludes that, "It is...the most egalitarian rather than the richest developed countries which have the best health." (Wilkinson, 1996: 76). He argues that if income redistribution can raise the health levels in rich and developed countries, it is the poor who benefit from extra monetary input rather than the rich suffering from their monetary output (Wilkinson, 1990: 395). 


\section{Social Capital and Health Inequalities}

Wilkinson believes countries with more equal income distribution are prone to offer better public health services as a type of social capital (Wilkinson, 1992: 167). Social capital is defined by Nan Lin (2001: 29) as "resources embedded in a social structure that are accessed and/or mobilized in purposive actions". Alejandro Portes (1998: 1-24) further explains how people enjoying social capital are benefitted. Robert D. Putnam (1995: 67) agrees with both Lin and Portes, and in cohesion with Durkheim's sociological theory of social integration and cohesion. Durkheim's philosophy illustrates that socio-individual ties, or what Bryan Turner calls social interconnectedness, derive regulatory norms and social supports that in turn regulate social actions (Gabe, et al., 2013: 41) (Turner, 2004: 295). From Durkheim's (1951) interest in social integration and social regulation to Turner's (2003: 4-20) in social involvement and social isolation, social capital remains an indispensable social factor of health and illness. Ichiro Kawachi et al.'s (1999: 1187-93) study in the United States supports Durkheim and Turner's theories with statistical findings, although similar findings and conclusions are rarely replicated in other research. From Gerry Veenstra's study (2000: 619-29) in Canada to Espen Dahl and Ira Malmberg-Heimonen's more recent research (2010) in Norway, none of statistical evidence significantly reveals an association between social capital variables and illness. However, the latter identifies "satisfied neighborhoods" and "social trust" as attributors to better health, which will be discussed later (Gabe et al., 2013: 42-3).

In 2000, Gerry Veenstra identified a close relationship between social isolation and poor health in Canada. He further noted that people living in neighborhoods with a lack of social capital are more likely to be socially isolated (Berkman et al., 2000: 137-73). Both verify Durkheim's sociological theory that the deficiency in social integration and social regulation exposes individuals to illness (Turner, 2004: 22). Richard Eckersley and Keith Dear (2002: 1891-904) echo Durkheim's theory, as they analyse the possible factors contributing to the global rise of suicide rates among young men in the last half-century. Primarily they attribute trends to the failure of developed countries to secure social identity and attachment for individuals. Furthermore, they condemn the development of individual autonomy, which diminishes for bonds to form between individuals and societies. In reference to the reinforcement of social identity and attachment, Carl Latkin and Aaron D. Curry reassert the need for social policies to improve public housing vacancies, control drug-use and provide other social services, in order to improve general health levels (Latkin et al., 2003: 41). Sarah Nettleton and Rodger Burrows (1998: 731-53) recognise that homeownership policies such as these facilitate the formation of a sense of identity, or what Ronald D. Laing (1959) has dubbed "ontological security", among individuals. Since the rise of social capital could potentially enhance social health, directly or indirectly, equalising the amount of social capital among countries might therefore serve as a means to reduce health inequality.

Wilkinson understands the importance of an individual's sense of identity and as a result, he encourages active engagement in social and voluntary activities, as he believes these results in higher hospitality and compassion within a society (Wilkinson, 1996: 4). Turner claims such social contact can act as a buffer against disease (Turner, 2004: 4) (Turner, 1993:2). Putnam (1995) argues that continuous interaction among people binds individuals by mutual trust, as mentioned earlier. Simon Szreter and Michael Woolcock (2004: 655) explain that respectful and trusting ties are gradually evolved from the individual level, to the dynamics between institutions and individuals (Gabe et al., 2013: 42). Putnam believes such trustworthy relationships and social support moderates the psychosocial stresses that can compromise health (Gabe et al., 2013: 42). Research from George W. Brown and Tirril Harris (1978) demonstrates that two-thirds of women suffering from clinical depression in Britain underwent certain level of deprivation or other psychosocial adversities (Turner, 2004: 17). This included the loss of parents or jobs. One of the means to form new attachments with individuals and/or societies, as presented by Peggy Thoits and Lyndi Hewitt (2001: 115-31), and Marc Musick and John Wilson (2003: 259-69), is social engagement in voluntary work. Turner concludes that such means of regular social involvement fosters the desired ends of decent psychosocial health (Turner, 2004: 17).

Rather than acting as supplements, Oral McDonnell believes social capital and income inequalities form reciprocal relationship in health inequalities. Countries with the highest income disparity, including the United 
States, maintain a relatively low stock of social capital. Denmark and Sweden, alternatively, have long enjoyed a reputation for secured social welfare and egalitarian income distribution (Gabe et al., 2013: 43). These findings demonstrate that the level of social capital and income inequality have a crucial impact on health inequalities. Robert Faris and Warran Dunham (1939) studied psychiatric patients in Chicago. They discovered that the diagnosis of schizophrenia was a by-product of both the disadvantages in class and income, as well as a deficiency in social cohesion. Anna M. Ziersch and Fran Baum (2005: 71-86) echo the significance of social capital, and in particular the entitlement of socio-economic privileges, when fostering better mental health.

\section{Psychosocial Challenges and Health Inequalities}

Bruce G. Link and Jo C. Phelan (1995: 80-94) suggest an emphasis on psychosocial mechanisms when maintaining good health (Coburn, 2000: 137). This can be viewed as the psychosocial approach - the third stage to approaching health inequalities - as named by Scambler (Scambler, 2015). Wilkinson argues that socioeconomic difficulties are associated with psychosocial illness (Wilkinson, 1996: 184). More specifically, Irene Mattisson et al. demonstrate a strong binding between job insecurity and psychiatric issues, in which unemployed people are at least four times more likely to divulge psychiatric symptoms (Mattisson et al., 1990: 461-6). In spite of the belief that either nature or nurture compromises psychological health, the ongoing statistical evidence, as noted by Michael Meaney, in both animal and human subject studies, demonstrate that environment can modify genetic expression (Meaney, 2001: 1161-92). Based on Michael Meaney's argument, even if individuals are born without mental challenges, social stressors, including job insecurity, could possibly induce a genetic modification and increase the likelihood of psychiatric illness. However, deprivation and the sense of insecurity do not necessarily impair an individual's mental health. The development of resilience, conceptualized by Norman Garmezy, Michael Rutter and their colleagues in the 1980s, helps insulate individuals in disadvantaged positions from mental disorder (Rutter, 2007: 205-9). In accordance with longitudinal research, David Pilgrim and Anne Rogers suggest that middle aged people are most capable of optimizing their use of resilience (Pilgrim et al., 2010: 49).

\section{Future Sociological Agendas}

\section{The need for more quantitative sociology staffing}

The above arguments and debates demonstrate socioeconomic factors contributing to the understandings of health inequalities in rich and developed countries in the contemporary context. As Scambler emphasises, sociological determinants of health inequalities play important roles in the public health discipline (Scambler, 2015). In order to better address health inequalities from a sociological perspective, Scambler and David Coburn suggest quantitative research should be promoted in medical sociology due to its contemporary shortage (Scambler, 2015). Quantitative research is vital, since public health data, on a national or international scale, cannot be collected and interpreted empirically but only by using quantitative analysis. However, the dispersion in terms of findings in existing quantitative research, for example the social capital-illness research debate, as mentioned above, demonstrates the need for sociologists to critically investigate the current adopted metrics.

\section{The need for new socioeconomic and public health metrics}

Scambler criticizes both "social class based on occupation" (SC) and socioeconomic classification (SEC) as a far from compelling proxy for class (Rose et al., 2003). A more comprehensive and representative proxy, neoWeberian National Statistics Socioeconomic Classification (NS-SEC), was therefore introduced in England and Wales (Rose et al., 2009). Under NS-SEC, Ann Langford and Brian Johnson credit the accurate measurement of occupation for its wider and better coverage by "reward mechanisms", "promotion prospects", "and autonomy "and "job security". There is also a more detailed classification of occupational status, from "senior professionals" to "never worked" (Langford et al., 2010: 1-28). Wilkinson, however, condemns the low credibility of data generated from such a rigid and robotic classification. For example, as he points out, rich and successful lawyers are placed in the same category as their poor counterparts. The occupational 
classification therefore creates a misrepresentation of class (Wilkinson, 1996: 59). Furthermore, Wilkinson again challenges the measurement of occupation on fairness grounds. Since employees approaching retirement are more likely to take up jobs with lower status than in their "golden age". Therefore, the effects from the variation of age-group remain unexplained in NS-SEC (Wilkinson, 1996: 59).

Aside from class measurement, the prevalence public health metrics is problematic for other reasons. One of most recognized proxies for health would be the Quality-Adjusted Life Year (QALY), which is still in use by World Bank, World Health Organization and National Institute for Health and Care Excellence in the United Kingdom (National Institute for Health and Care Excellence, 2013). It measures the quality of life of a subject via a weighting of years in life spent with a disability (Weinstein et al., 1997: 716-21). In quantitative research, it is necessary for sociologists to quantify quality of life, an ambiguous and subjective concept. Some patients may rather extend their life despite suffering from persistent medical disabilities or challenges; while others prefer maximizing the enjoyment of remaining life and resist medical treatments (Murray et al., 1996). This again indicates the shortcomings from measuring quality of life in public health metrics. Consequently, in the future, while sociologists should expand their quantitative research fields when examining health inequalities, sociologists should strive to improve their empirical skills in metric development and measurement, insofar as is possible.

\section{The need for critical sociology development}

As Scambler has noted, sociology should continue its philosophy of being thoughtful and critical (Scambler, 2015). However, in recent decades, the pervasiveness of fraud and manipulated research data has highlighted the importance of reinforcing the position of critical sociology. In the United States, for example, approximately $60 \%$ of pharmaceutical grants are allocated to commercial research organizations instead of universities. While the former are widely recognized as economically efficient, their lack of independence and critical judgment mean that any findings should be viewed skeptically. Howard Waitzkin, for example, criticizes medical opinions, arguing that they are often manipulated by commercial pharmaceutical giants, multinational corporations in particular (Waitzkin et al., 1974). Furthermore, data from such companies are not bound to the customs of publication nor being publicly criticized (Turner, 2004: 281). In the future, critical sociology should reinforce its position in society. More publication of sociological work and, in consequence, more public and constructive criticism on others' effort can ensure a fairly high level of independence, objectivity and room for improvement in social research.

\section{Conclusions}

In medical sociology, a common approach recognises that the social patterning of disease can be viewed through a lens of "mode of social organization". Whilst The Marmot Report empirically concludes that health inequalities cannot be explained simply via genetic makeup, sociologists, including Wilkinson and Turner, do believe there are some hidden factors from the nurture that contribute to health inequalities. As The Black Report states, class difference does not impact upon health inequalities directly, but socioeconomic factors derived from class are pivotal. The absolute income level would be an obvious indicator of the socioeconomic position of a country. However, Wilkinson, Marmot and Smith are not satisfied with its association with health inequalities. Indeed, the contrast between Japan and Britain indicates that an egalitarian income distribution, instead of a high level of absolute income level, contributes to better health equality. "It is...the most egalitarian rather than the richest developed countries which have the best health," Wilkinson argues. As mentioned above, a country with a more egalitarian income distribution is usually one with more social capital. Latkin and Curry note the importance of productive social policies and Wilkinson suggests that active participation in voluntary work help facilitate a sufficient level of social capital. Hence, a solid social attachment and a vibrant social integration among individuals can be created. These in turn foster the development of mutual trust, both among individuals and between individuals and societies. If as social tension and stressors are eased, the psychological health of the general public can be improved. These help explain why countries with more social capital are healthier. To better address health inequalities, quantitative and critical sociology 
are in demand. In the future, sociologists should provide explanations of health issues built upon more evidence-based findings. Furthermore, they should seek better alternatives, in terms of public health metrics, to measure health inequalities. Through the continuous publishing of their research and allowing public criticism of their research approaches, a more accurate interpretation of health inequalities can then be encouraged.

\section{Bibliography}

1. Action on Smoking and Health (1993) Her share of misfortune, London: ASH

2. Annendale, E. (2010) "Health status and gender", The New Blackwell Companion to Medical Sociology, Oxford: Wiley-Blackwell

3. Annandale, E. (2013) "Gender", In Jonathan Gabe and Lee Monaghan, Key Concepts in Medical Sociology (2nd Edition), London: Sage (http://dx.doi.org/10.4135/9781526401687.n2)

4. Berkman, L. (2000) "Social integration, social networks, social support, and health", In Norman Anderson, Encyclopedia of Health and Behavior: SAGE Publications, pp. 137-73

5. Blaxter, M. (1990) Health and Lifestyles, Routledge: London

6. Coburn, D. (2000) "Income inequality, social cohesion and the health status of populations: the role of neo-liberalism", Social Science and Medicine, Vol. 51 (1), pp. 135-46

7. Smith, G. et al. (1992), "Magnitude and causes of socioeconomic differentials in mortality: further evidence from the Whitehall Study", Journal of Epidemiology and Community Health, Vol. 44 (4), pp. 265-70

8. Department of Health (1990) On the state of the public health for the year 1989, London: HMSO

9. de Maio, F. (2010) Health and Social Theory, London: Palsgrave Macmillan

10. Eckersley, R. et al. (2002) "Cultural correlates of youth suicide", Social Science \& Medicine, Vol. 55 (11), pp. 1891-1904

11. Faris, R. and Dunham, H. (1939) Mental Disorders in Urban Areas, Chicago: University of Chicago Press

12. Karwachi, I. et al. (1999) "Social capital and self-rated health: a contextual analysis", American Journal of Public Health, Vol. 89 (8), pp. 1187-93

13. Laing, R. (1959) The Dividend Self, London: Tavistock

14. Langford, A. et al. (2010), "Trends in health inequalities in male mortality, 2001-08: intercensal estimates for England and Wales", Health Statistics Quarterly, Vol. 47 (1), pp. 1-28

15. Latkin, C. A. et al. (2003) "Stressful neighbourhoods and depression: A prospective study of the impact of neighbourhood disorder", Journal of Health \& Social Behaviour, Vol. 44 (1), pp. 34-44

16. Lin, N. (2001) Social capital: A theory of social structure and action, Cambridge: Cambridge University Press 
17. Link, B. et al. (1995) "Social conditions as fundamental causes of disease", Journal of Health and Social Behavior, Special No, pp. 80-94

18. Marmot et al. (1989) "Why are the Japanese living longer?" British Medical Journal, Vol. 299 (6715), pp. 1547-51

19. Mattisson, I. et al. (1990) "Threat of unemployment and cardiovascular risk factors: longitudinal study of quality of sleep and serum cholesterol concert ratios in men threatened with redundancy", British Medical Journal, Vol. 301 (1990), pp. 461-6

20. McCord, C. et al. (1990) "Excess mortality in Harlem", New Gangland Journal of Medicine, Vol. 322 (3): 173-7

21. Meaney, M. (2001) "Maternal care, gene expression and the transmission of individual differences in stress reactivity across generations", Annual Review of Neuroscience, Vol. 24 (1): 1161-92

22. Murray, C. et al. (1996) The Global Burden of Disease: A comprehensive assessment of mortality and disability from diseases, injuries, and risk factors in 1990 and projected to 2020: Harvard University Press

23. Musick, M. et al. (2003) "Volunteering and depression: The role of psychological and social resources in different age groups", Social Science \& Medicine, Vol. 56 (2), pp. 259-69

24. National Institute for Health and Care Excellence (2013) Guide to the methods of technology appraisal 2013 (https://www.nice.org.uk/process/pmg9/chapter/foreword)

25. Nettleton, S. et al. (1998) "Mortgage debt, insecure home ownership and health: an exploratory study", Sociology of Health and Illness, Vol. 20 (5), pp. 731-53

26. Organisation for Economic Cooperation and Development (OECD) (1991) National accounts: main aggregates, Vol. 1, pp. 1960-89

27. Pilgrim, D. et al. (2010) "Social Class and Mental Health", A Sociology of Mental and Illness: Open University Press

28. Portes, A. (1998) "Social capital: Its origins and applications in modern sociology", Annual Review of Sociology, Vol. 24 (1), pp. 1-24

29. Putnam, R. (1995) "Bowling alone: America's declining social capital", Journal of Democracy, Vol. 6 (1), pp. $65-78$

30. Rodger, G. (1979) "Income and inequality as determinants of mortality: an international cross-section analysis", Population Studies, Vol. 33 (2), pp. 343-51

31. Rose, D. et al. (2003), A Researcher's Guide to the National Statistics Socioeconomic Classification, London: Routledge

32. Rose, D. et al. (2009) Social Class in Europe: an Introduction to the European Socioeconomic Classification, London: Routledge

33. Rutter, M. (2007) "Resilience, competence, coping", Child Abuse \& Neglect, Vol. 31 (3), pp. 205-9

34. The Marmot Review (2010) Post-2010 Strategic Review of Health Inequalities (The Marmot Review), London: The Marmot Review

35. The Tobacco Atlas (2015) "Consumption" (http://www.tobaccoatlas.org/topic/cigarette-use-globally/) 
36. Thoits, P. et al. (2001) "Volunteer work and well-being", Journal of Health \& Social Behaviour, Vol. 42 (2), pp. 115-31

37. Townnsend, P. et al. (1988) "The Pattern of Present Health Inequalities" "Towards an Explanation of Health Inequalities", Inequalities in Health: The Black Report and the Health Divide, Harmondsworth: Penguin

38. Turner, B. (2003) "Social capital, inequality, and health: The Durkheimian revival", Social Theory \& Health, Vol. 1 (1), pp. 4-20

39. Turner, B.S. (2004) The New Medical Sociology: Social Forms of Health and Illness, New York/London: Norton \& Co.

40. Scrambler, G. (2002) Health and Social Change: A Critical Theory, Buckingham: Open University Press

41. Scambler, G. (2012) "Review article; health inequalities", Sociology of Health and Illness, VOI. 34 (1), pp. 130-46

42. Scambler, G. (2013) "Social Class", In Jonathan Gabe and Lee Monaghan, Key Concepts in Medical Sociology (2nd Edition), London: Sage (http://dx.doi.org/10.4135/9781526401687.n1)

43. Scambler, G. (2015) "Understanding in inequality: Street protests and health care reform" (http://onlinelibrary.wiley.com/journal/10.1111/(ISSN)1467-9566/homepage/podcast__key_thinkers_and_debates.htm?)

44. Szreter, S. et al. (2004) "Health by association? Social capital, social theory, and the political economy of public health", International Journal of Epidemiology, Vol. 33 (4), pp. 650-67

45. Veenstra, G. (2000) "Social capital, SES and health: an individual level analysis", Social Science \& Medicine, Vol. 50 (5), pp. 619-29

46. Waitzkin, H. et al. (1974) The exploitation of illness in capitalist society, Indianapolis, Ind.: Bobbs-Merrill

47. Weinstein, M. et al. (1977) "Foundations of cost--effectiveness analysis for health and medical practices", The New England Journal of Medicine, Vol. 296 (13), pp. 716--21

48. Wilkinson, R. G. (1986) "Income and mortality", Class and health: research and longitudinal data, London: Tavistock, pp. 88-114

49. Wilkinson, R. (1990) "Income distribution and mortality: a "natural experiment", Sociology of Health and Illness, Vol. 12 (4), pp. 391-42

50. Wilkinson, R. (1992) "Income distribution and life expectancy", British Medical Journal, Vol. 304 (1), p. $165-8$

51. Wilkinson, R. (1996) Unhealthy Societies: the Afflictions of Inequality, London: Routledge

52. Ziersch, A. M. et al. (2005) "Neighborhood life and social capital: the implications for health", Social Science \& Medicine, Vol. 60 (1), pp. 71-86 